CHAPTER 2

\title{
Salamanca in the New World
}

\author{
University Regulation or Social Imperatives?
}

\author{
Enrique González González
}

\section{Introduction}

The official opening day of the University of Salamanca, eight centuries ago, was commemorated with numerous academic ceremonies. There have been debates - that will undoubtedly continue - about the solidity of the historical foundations of this ephemeral event. An undeniable fact is that the university was not born mature and it had to be affirmed over the centuries, over a period that involved countless vicissitudes of fortune. ${ }^{1}$ It is also true that, when Salamanca began to be a subject of interest for the New World and the New World for Salamanca, the university was experiencing its golden age and the height of its prestige.

Given that this present volume contains several studies on the so-called "School of Salamanca", ${ }^{2}$ I will limit myself to raising some general considerations about the university and the possible links between it and those established in the Indies and the Philippines from the 16th to the 18th centuries. I shall begin with a brief historical overview to highlight some notable features of the institution that undoubtedly were important reference points for its transatlantic counterparts. I will move on to propose the extent to which Salamanca's historiography has conditioned a certain image regarding its bonds with Spanish America and the Philippines, questioning the traditional thesis that the university was, without further interpretation, immutably "transplanted" to the Indies. Thirdly, I will analyse the features of Salamanca's legislation, its relationship to those adopted by the various universities of the New World, and the relevance of such influence in the definition of the New World universities. Finally, and as a proposal for future studies, I will suggest other possible links between studia in the Peninsula and the Indies: scholars from Salamanca settled in America, criollos studied and taught in Salamanca,

\footnotetext{
1 Beltrán de Heredia, Los orígenes de la Universidad de Salamanca; García y García, "Génesis de la Universidad de Salamanca”; Peset, "La corporación en sus primeros siglos, XIII-XV”.

2 For a recent approach, see Duve in this volume.
} 
agents of the empire graduated from the University of Salamanca, and, most importantly, authors from both continents circulated in the classrooms, and handwritten and printed works arrived in the institutional and private libraries of intellectuals in both territories.

Salamanca was reconquered in 1088 and repopulated with great speed. The strategic Roman bridge over the Tormes River opened the way to the south for the troops of Castile and Leon. ${ }^{3}$ The king of Leon entrusted the government of the city to the husband of the future Queen Urraca, Count Raymundo of Burgundy (who died in 1107), who gave a municipal charter to the city, establishing its town hall. In the middle of the century, Ferdinand II (who governed from 1157 to 1188) confirmed the municipal body. ${ }^{4}$ The bishopric was restored in 1102 and the cathedral was in an advanced state of construction in 1120 when its first prelate died. ${ }^{5}$

It was within the context of the Reconquest that the University of Salamanca was established in 1254 as a university of students, erected and endowed by the king, and immediately approved by the pope. Because the professors enjoyed a salary or stipend, they soon had a greater weight in the institution at the expense of the student, to such an extent that they formed a parallel collegio of doctors, which was presided over by a primicerius. The precise date it was established is unknown, but it was certainly active at the beginning of the 15th century. ${ }^{6}$ The constitutions of Martin V in 1422 sanctioned a new correlation of forces and from then on, governance passed to a faculty formed by the rector (a scholar), the chancellor (maestrescuela, judge of the corporation who was a doctor), and 20 representatives of students and doctors called definidores. Ten of the definidores were students and the rest were doctors, who may or may not have been lecturers. This legal body replaced the assemblies of students, who previously gathered in a general assembly (claustro pleno) to define the course

3 Real de la Riva, La Universidad de Salamanca, 5-6.

4 Sánchez Ruano (ed.), Fuero de Salamanca. This document includes various dates. Reference to the Count Raymundo of Burgundy, Law 315; Law 274 begins, "Plogo a nostro sennor el rei don fernando que todo el poblo de salamanca sea un conceio".

5 Sánchez y Sánchez, "Catedral y universidad, una relación secular".

6 Esperabé, Historia pragmática e interna de la Universidad de Salamanca. On 15 September 1401, Enrique III wrote to "el rector e collegio e estudiantes de la çibdat de Salamanca", vol. 1,64 . 
of their own education. According to Lorenzo Luna, this was how Salamanca became a complex institution that integrated students and doctors in a single body. ${ }^{7}$ The merger of the two original corporations, far from supporting a "democratic" balance of powers, ${ }^{8}$ precipitated the decline and accelerated the loss of the students' influence, and supported the growing strength of the doctors, which would only increase in the early modern period. This trend was not exclusive to Castile: it also appeared in Italy, especially in Bologna, and in places where lecturers were paid for by the city or an external authority. ${ }^{9}$ This pattern of a "doctoralised" university would pass on to the New World in the 16th century.

In terms of finances, the University of Tormes, which had been founded and endowed by the king, was strongly influenced by the papacy in the Middle Ages. During this period, the pope ordered several visitations, including that of Cardinal Pedro de Luna in 1381 which generated the first body of constitutions. Later on, Luna, who became Pope in 1394 (Benedict XIII), dictated new rules (1411) in which he tried to increase the authority of the rector and establish a more rigorous administration of the rents. ${ }^{10}$ In 1422, Martín v sanctioned the final constitutions of the university, which, supposedly, were still in force until the introduction of the 19th-century radical liberal reforms. ${ }^{11}$

This clear papal influence over the university during the Middle Ages has led historians to underestimate the royal presence in the institution. Nevertheless, there were almost a hundred royal charters issued between the ${ }^{13}$ th and $15^{\text {th }}$ centuries, ${ }^{12}$ mainly at the request of the corporation itself, which also had royal financing. This kind of royal funding was a sign of compliance with the royal authority that was necessary for confirming and guaranteeing its privileges, especially those intended to stop municipal intrusions. In 1411, the maestrescuela submitted the constitutions of Benedict XIII for Juan II's approval and he endorsed them and appointed himself the "patron of the said studium".13 During the reign of the Catholic Kings in the last quarter of the 15th century, royal influence over the university experienced a substantial growth, partly due to the political stability achieved by Castile and its

Luna Díaz, "Universidad de estudiantes y universidad de doctores", 33.

8 Beltrán de Heredia, Cartulario de la Universidad de Salamanca, vol. 1, 17; among others.

9 Bellomo, Saggio sull'università nell'età del diritto comune, especially chapter 11.

10 Luna Díaz highlighted the fact that 16 of the 32 constitutions dictated by Benedict XIII dealt with pecuniary matters, "Universidad de estudiantes y universidad de doctores", 18.

11 Constitutiones [...] almae Salmanticensis Academiae.

12 Esperabé, Historia pragmática, vol. 1, 19-134.

13 Esperabé, Historia pragmática, vol. 1, 85; 92-94. 
monarchy in this period. Kings tried to control the university's life through visitors and the presence of kings and his visitors increased substantially during the 16th century. These kinds of regulatory practices were extended to other universities in Spain and America. The compilation of documents regarding the history of the University of Salamanca published by Esperabé includes 73 letters sent by Emperor Charles $\mathrm{V}$ to the studium of Tormes, and 310 by Philip II..$^{14}$

This increasing royal influence brought an end to the papal visits. From that period onwards, royal envoys negotiated internal reforms with the claustro, which was already under the control of the doctors..$^{15}$ Without formally abrogating the code of Martin v, new statutes endorsed by the king in 1538 tacitly overrode part of the old papal rules.

Legislative changes tended to justify new power relations and, at the same time, responded to the growth of the university, which saw a steep rise in enrolment and, consequently, in the number of chairs. Alfonso x endowed 11 of those chairs in 1254 (grammar, music, arts, medicine, law, and canon law) and, in 1411, Benedict XIII consolidated 25 cátedras de propiedad (permanent chairs). The faculty of theology was officially created in 1416 and three new chairs were created when the Franciscan Monastic studium and the Dominican studium of San Esteban joined the university. By the middle of the 16th century, 57 chairs had been created, but only the 25 chairs founded by Benedict XIII in the $15^{\text {th }}$ century maintained their permanent status; the other 32 were granted for a limited period only (three to six years). The owners of these chairs also received a much lower salary. ${ }^{16}$ Furthermore, following the demands of the students, a certain number of catedrillas, positions with little or no pay, were created. These precarious teaching assignments were also temporary and disappeared when student enrolment decreased.

As for the number of students, it is difficult to estimate how many there were in the first three centuries as the records of enrolments preserved in the university archives only start in 1545 . Moreover, studies that collect and examine the abundant documentation about scholars, chairs, and students during the Middle Ages are lacking. However, there are some studies that analyse the lists of beneficia expectationes, in which clerical students and graduates applied for different ecclesiastical offices granted by the pope. These lists, by definition, excluded secular students and included only a part of the clergy, but

\footnotetext{
14 Esperabé, Historia pragmática, vol. 1, 373-627.

15 See the section below, "Dictate Laws, Apply Laws?".

16 Peset and González González, "Las facultades de Leyes y cánones”, 25-31.
} 
they allow us to get a sense of which studies were in strong social demand. ${ }^{17}$ The number of applications increased and decreased over time. For example, the enrolment of 1381 listed 326 candidates with the number of applications decreasing to 110 in 1393 but rising again to register 311 candidates in 1403 . Such changes related to lesser-known political and social circumstances that would need to be explained by future studies. Other evidence shows that the school census easily exceeded 500 enrolled students between the 14th and the 15th centuries. This success allowed the University of Salamanca to undertake important material improvements. ${ }^{18}$

Much attention has been paid to the early modern enrolment records since the last third of the 2oth century and they have been published in different archival series. The Salamanca series has already been systematically studied. It is estimated that, in the 1560 os, the annual average of students fluctuated between 4,686 and 5,066 and that in the 1570s, it exceeded 6,ooo, growing even more in the following decade. The $1585^{-15} 86$ enrolment recorded 6,938 students, the highest ever number of students, which was followed by a slow and irreversible decline that accelerated in the second half of the 17 th century, with only 1,600 students registered in 1700 . There was a slight increase in the $1840 \mathrm{OS}$, but the century closed with the same average of 1,6oo students per year. ${ }^{19}$

In the 1970s, Stone argued that an "educational revolution" took place in Europe at the beginning of the early modern period as a reaction to the emergence of the great monarchies. ${ }^{20}$ Kings needed well-trained lawyers to consolidate their councils and jurisdictional institutions. At the same time, Catholic and other Christian denominations required well-educated personnel to defend their rights and privileges and guarantee proper pastoral care. This confluence between institutional needs and demands and student expectations would have been followed by the notable increase of students and universities mentioned above. Therefore, while there were only two universities under the Castilian Crown (Salamanca and Valladolid) at the end of the 15th century,

\footnotetext{
17 Goñi Gaztambide, "Tres rótulos de la universidad de Salamanca"; Peset and Gutiérrez Cuadrado, "Clérigos y juristas en la baja edad media castellano-leonesa", 26-30.

18 In 1378, the custodian (bedel) of the school of canon law proposed installing wooden floors to the cathedral chapter, which owned the building. He also attached benches to the walls and put others in the centre, a kind of reform that allowed "at least 200 students" to attend the courses. Beltrán de Heredia, Cartulario, vol. 1, doc. 71, 646-647. There is a lack of similar evidence about the students of grammar and arts, who were the most numerous.

19 Rodríguez-San Pedro, Polo Rodríguez and Alejo Montes, "Matrículas y grados, siglos XVIXVIII", 6o7-673, especially 619 and 633.

Stone (ed.), The University in Society.
} 
at the end of the 16th century, 18 universities were active in the main Iberian realm (not counting the recently created universities in Spanish America).

A similar dynamic is found in the Kingdom of Aragon. During the Middle Ages, several universities obtained founding charters but, due to different financial and political problems, only Lerida, Huesca, and Perpignan actually started operating and held permanent educational activities. New universities appeared from 1500 onwards. Moreover, those that had been founded in the Middle Ages but that had never functioned regularly were finally inaugurated and began to attract students. By the end of the century, there were 12 "living" universities in the Kingdom of Aragon. ${ }^{21}$ However, in places where the royal offices, ecclesiastical beneficia, and other bureaucratic positions became part of the inheritance of certain families - as was especially common in France and England - or of closed elitist groups - like the Castilian colegios mayores and the expectations for promotion by education diminished, enrolment fell, as happened in many places throughout the ancien régime. ${ }^{22}$ In contrast, the number of enrolments at universities continued to be high where academic institutions remained open spaces for promotion and where university studies and degrees continued to be important tools to achieve and acknowledge social position, as we will see in Spanish America. In other words, both the increase and decrease in the number of students that one can perceive in the enrolment registers was neither accidental nor disconnected from the evolution of other academic and political institutions.

The Catholic Kings established that a university degree in law was necessary to practice law in the secular and ecclesiastical courts. ${ }^{23}$ The Council of Trent required that bishops, as well as those applying for offices in ecclesiastical chapters, had to hold a licentiate degree or be doctors in theology or canon law. ${ }^{24}$ These decrees were not always followed but had an enormous impact in the following years. In the Indies, the councils of the big cities urged the king to found universities so that the children of Spaniards, who were eager to obtain some of the many newly-created secular and ecclesiastical positions, could be trained and obtain university degrees. In the absence of systematic studies, the historiography on the colonial Spanish-American universities tends to consider that, contrary to the European dynamic of rise, crisis, and

21 De Ridder-Symoens, (ed.), A History of the University in Europe; Martínez López-Cano, (ed.), La Universidad novohispana.

22 Stone (ed.), The University in Society; Julia, Revel and Chartier (eds.), Les Universités Européennes du XVIe au XVIIIe siècle; Peset, "Historia cuantitativa y población estudiantil".

23 Tormo Camallonga, El Colegio de Abogados de Valencia, 183 and the following pages.

24 Sacrosanto y ecuménico concilio de Trento, session 23 , De reformatione, 5-15. 
stagnation, university enrolment in Spanish America grew in the 16th century and remained stable until the crises of 1810. It seems that young criollos still considered university studies and degrees as a useful strategy for social and economic promotion. In Mexico, a visitor supervised six of the nine chairs that were held in 1583 , counting 101 students, ${ }^{25}$ and, during the 18th century, annual registration oscillated between 607 and 1,100 students. ${ }^{26}$ An ongoing study about the University of Guatemala reveals that registration began in 1699 with only seven students but in 1744, 76 students were enrolled and, after a temporary decline, the number of students grew to 188 in $1799 \cdot{ }^{27}$ The University of Córdoba (Argentina) was first established by the Jesuits in 1623, administered by the Franciscans following the expulsion of the Jesuits in 1767 , and finally secularised in 1808. The five-year average for the enrolment in the arts during the Jesuit administration fluctuated between 30 and 84 students, the Franciscans managed to attract between 42 and 72 students, and 90 students attended the courses every academic year from 1808 to 1810 . The number of students declined in the following five years, with only 29 pupils attending the studium cordubensis during this period due to the tumults of independence and uncertainty. ${ }^{28}$ Leaving aside the final years of the Spanish colonial period, these three cases demonstrate a clear increase in the number of students between the 16th and the 18th centuries.

During the Enlightenment, the decline of Salamanca continued, reaching its lowest ebb at the beginning of the 19th century when Napoleon took over the city (1809-1813) and the university and colleges were sacked, ruined, and lost their income. In 1830, Ferdinand viI decided to close all the universities of the kingdom and when Salamanca reopened two years later, it was devastated. The situation further declined in 1838 with the secularisation reforms which closed all the monasteries of the city, including the famous Dominican Monastery of San Esteban, and the faculty of medicine was closed in 1845 . From then on, physicians could only study and obtain university degrees at the Universidad Central de Madrid. The faculty of theology was abolished in 1868 as a result of legal and political changes in favour of the secularisation of the university. Enrolment in Salamanca fell to 150 students in 1809 but slowly increased throughout the 19th century, reaching 1,100 students in the $1890 \mathrm{os}$.

25 Pavón, "La población de la facultad menor", 93-94.

26 Peset, "Historia cuantitativa y población estudiantil", especially Appendix 2, 246-250.

27 Álvarez, Dos reales y obediencia al rector. I am very grateful to Prof. Adriana Álvarez for sharing some important results of her unpublished research with me.

28 González González and Gutiérrez Rodríguez, "Estudiantes y graduados en Córdoba". A similar account in Ramírez, La Universidad de Córdoba. 
That number fell again to between 800 and 900 students at the beginning of the 2oth century. ${ }^{29}$ It was within this context of decline and patrimonial devastation that historians began to write about the history of the University of Salamanca.

\section{The University's Past: From the First Apologetic Approaches to the New Critical Analysis}

The historiography of the University of Salamanca shows a very clear qualitative and quantitative divide between what was written before the 1970s and what was written afterwards. This was the decade that saw the end of Franco's dictatorship, which was accompanied by the interruption of the censorship apparatus of the regime and the voluntary and forced end of any external attempts of reform. At the same time, as has already been stated, the last quarter of the century led to a fundamental reorientation of approaches to the university's past and present in both Europe and the Americas. Seminal works, such as those of Lawrence Stone ${ }^{30}$ and - within the Spanish context - Mariano and José Luis Peset, were published in this period of renewal. ${ }^{31}$

A summary of the most important publications dealing with the history of the University of Salamanca before 1975 can be divided into three periods: firstly, a few books and articles that were published in 19th century; secondly, texts written between the first-third of the 2oth century and the outbreak of the Spanish Civil War (1936); and finally, the period from 1937 to 1975 (the death of Franco). The literature reviewed here is based on a bibliography published in 2009 which includes 2,819 entries of books and articles published from 1801 until 2007. ${ }^{32}$ From that list, 78 items were recorded for the 19th century, 174 for the period between 1901 and the Spanish Civil War, and 546 for the period 1937-1975.

It should be noted that, in contrast to the relatively low levels of academic interest and number of publications concerning the University of Salamanca until 1975, this bibliography includes over 2,ooo entries for the period 19762007. The literature published after 1975, therefore, surpasses what was published from 1801 until that year. Barring some exceptions, this unprecedented

29 Hernández Díaz, "El ochocientos 2. De la Ley Moyano al siglo XX", 227.

30 Stone (ed.), The University in Society.

31 Peset and Peset, La universidad española. Siglos XVIIIY XIX.

32 Rodríguez-San Pedro and Polo Rodríguez, "Bibliografía sobre la Universidad de Salamanca (1800-2007)", 639-836. 
quantitative boom was accompanied by a substantial improvement in the quality of the literature about the history of Salamanca University.

The long crisis of the 19th century explains why, of the 78 titles collected for this period, many were official publications, press notes, or texts written in commemoration of certain events (at least one of them dealt with the stay of Columbus at San Esteban before sailing to the Indies). Apart from these non-academic publications, three general works of greater interest were published. Antonio Gil de Zárate (1793-1861), a former liberal minister, published three volumes about the history of public education in Spain. His De la instruccion pública en España (1855) provided the first systematic overview of the history of the university in Spain, with many references to the ancient University of Salamanca. Naturally, his works supported the secular reforms implemented by the constitutional governments, in which he had taken an active role. Another general history, also framed by the same prevailing liberal mentality, was the Historia filosófica de la instrucción pública en España, desde sus primitivos tiempos hasta el día, ${ }^{33}$ by Juan Miguel Sánchez de la Campa (1820-1885). The title is perhaps surprising for a modern reader, but Sánchez focused on the social and political philosophies that helped form ancient and modern educational systems and explored the role of public instruction in society. The first volume of his encyclopaedic approach made important references to Salamanca.

Finally, the work of the ultramontano Professor Vicente de la Fuente (18171889) also had a great impact. Almost at the end of his feverish editorial life, he published the four-volume Historia de las universidades, colegios y demás establecimientos de enseñanza en España (1884-1889). There, he rejected liberal reforms considering that, in his opinion, they were reducing universities to "offices of teaching" and proposed instead to "perpetuate the memory of what has been destroyed". ${ }^{34}$ His new approach, based on a deep analysis of legal documentation, severely condemned the destroyers of his imagined Arcadia. Several authors later returned to this kind of approach, offering similar apologetic perspectives. La vida corporativa de los estudiantes universitarios en su relación con la historia de las universidades (1914), written by Adolfo Bonilla $\left(1875^{-1926)}\right.$, is among the better known of such works. These antagonistic and irreconcilable views would have many defenders in the second historiographic period (1901-1936) but then vanished in 1937, when the only tolerated form of speech was fawning praise for the old university.

33 The first volume goes from prehistory to 1808.

34 "[...] oficinas de enseñanza [...] perpetuar la memoria de lo que se ha destruido", "Prólogo" to volume 1 . 
The 174 publications registered in the first-third of the 2oth century reveal a clear evolution from general works dealing with the history of education in Spain to a growing interest in the University of Salamanca. Three lay authors institutionally linked to the university were responsible for the most important historiographic contributions in this period. The first of these was Enrique Esperabé de Arteaga (1869-1966), who published the first volume of his Historia pragmática e interna de la Universidad de Salamanca in 1914. He was the son of the rector of the university from 1869 until 19oo, and he himself was also briefly rector from 1923 to 1930 . In a brief prologue, he outlined the general plan of a work that he imagined would be published in six volumes. The first volume focused on the relationship between "the University of Salamanca and the kings"; the second one, published in 1917, reviewed the personnel of Salamanca, the rectors and the "most distinguished professors and students ". Even though he lived for almost another half-century, the envisioned four subsequent volumes remained undone. Esperabé had planned to write one volume on the "the most notable literary actions and deeds", another on the relationship between the popes and the university, another on books of the university, and a final one which should have analysed economic topics, such as schools and rents. ${ }^{35}$ Even if Esperabé's series on the history of the University of Salamanca was never finished, the two published volumes are large tomes of over 2,ooo pages long. More than a historical study, Esperabé gathered massive documentary series, lists, and biographical data of the "most distinguished" figures of the university - hence the title's use of the word "pragmatic".

The first volume of Esperabés Historia pragmática included more than 70 royal charters issued between 1218 and 1512, almost 400 from the reigns of Charles V and Philip II, and many others that were promulgated by the monarchs of Spain, all the way until his contemporary Alfonso XIII. The university statutes of 1538 and 1561 were also published in this first volume. The second volume, which was more irregular and hastily written, devoted 242 pages to the rectors of the university from the $15^{\text {th }}$ until the 19th centuries, and 125 pages of high praise for the administration of Esperabé's own father. It also provided chronological or alphabetical series of some of the professors and illustrious students of Salamanca, along with notes of uneven quality. Its chronological range was also very wide, spanning from the 15th century to the 1910s. Even with all its errors, Esperabé's texts, which were not reissued after their initial publication, are still important works of reference. 
Among the laymen associated with the University of Salamanca, archivist Amalio Huarte Echenique (1882-1953) devoted some 20 short articles (published from 1915 to 1930) to exhume, in whole or in part, documents from the archives with information about famous professors, student life, and historical anecdotes among other things. ${ }^{36}$ In turn, professor Pedro Urbano González de la Calle (1879-1966), an expert on classical philology, studied university Latin and the writings of the famous humanist Franciscus Sanctius Brocensis (1523160o). Together with Huarte, he undertook a critical edition of the constitutions of Benedict XIII and Martin v. Supporting the democratic and socialist ideals of the Republican loyalists, he abandoned these studies when he was forced to go into exile in Mexico, where he died in 1966.

In the same period, some important writings were published by Dominicans living at San Esteban, which had already been institutionally separated from the university. The first of these authors was Justo Cuervo (1859-1921), followed by Luis Getino (1877-1946) - founder of the emblematic historical review of the order, Ciencia tomista, in 1910 - and finally, Venancio Carro (1894-1972). The point on which they converged - more than a particular interest in the university as such and reflections on its complexity - was their belligerent desire to exalt the role of the Dominican order in the 16th and $17^{\text {th }}$ centuries. They published some of the main writings of the leading Dominican figures in the field of theology: Francisco de Vitoria, Domingo de Soto, Melchor Cano, and Domingo Báñez. When they mentioned writings or ideas coming from other mendicant orders and theological schools, they disqualified them as jealous rivals of the great Dominican masters, accusing them of deviating from "pure" Thomism. Hence their fierce and aprioristic condemnation of nominalism and their unanimous approval of their fellow brothers in the theological debates that were held with the Jesuits, especially in the harsh polemic known as De auxiliis. Only exceptional figures from other mendicant orders, such as the Augustinian Fray Luis de León, earned their general applause.

Because of this apologetic eagerness, Cuervo, Getino, and Carro limited their interest to the Dominican brothers, theologians, and philosophers of what they called the "Golden Years" of Spain and the friars of Saint Dominic, that is to say, from the beginning of the 16th century to the first-half of the 17th century. They almost completely neglected those Dominicans who lived in "decadent" times and the intellectual production of other important faculties such as civil and canon law, which were dominated by laymen or secular 
clerics, and, moreover, medicine. Vicente Beltrán de Heredia (1885-1973), the youngest, most prolific, and most influential brother of the group claimed,

If the Spanish university of the Golden Age has such a relevant personality in history, it is mainly due to Theology [...] The prestige of Theology was, then, qualitative, not quantitative [...] Talking about Theology in our Universities is, therefore, to talk about what it is more glorious and encouraging in the life of these. ${ }^{37}$

On another occasion Heredia told their Spanish compatriots that "the science of the spirit [sc. theology] seems to have been the portion of knowledge that Providence has reserved for us". ${ }^{38}$

Due to his vast and voluminous writings, Beltrán de Heredia, active almost until his death in 1973, is the hinge point between the intellectual production of the early 2oth century and the literature written during the Franco dictatorship. During these four decades (1930s-1960s), the literature about the university's history experienced a notable growth. In contrast with the 174 publications written during the first-quarter of the century, between the early $1930 \mathrm{os}$ and the end of the 1960s, 546 new academic writings were dedicated to the Salamanca studium.

In 1911, Fray Luis Getino, residing in Madrid, requested Beltrán de Heredia's editorial support for the newly created Ciencia Tomista, and the editors moved the journal's editorial office to Salamanca in 1928, where Vicente Beltrán lived until his death. His editorial work, precociously started in 1911, led him to write more than 300 "critical notes" as well as more than 100 articles (most of them for Ciencia Tomista). He selected and compiled some of these in the Miscelánea Beltrán de Heredia (1972), including 68 studies in four large volumes which spanned more than 2,500 pages. At the same time, he also published 14 books in 32 volumes. In the period he spent in Madrid, Beltrán de Heredia also studied other Spanish theological faculties of the 16th century, including two Spanish American faculties controlled by Dominican friars. In Salamanca, he usually concentrated on local theologians, institutions, and polemics, although he did

37 "Si la Universidad española del Siglo de Oro tiene personalidad tan relevante en la historia, se debe principalmente a la Teología [...] El prestigio de la Teología era, pues, cualitativo, no cuantitativo [...] Hablar de la Teología en nuestras Universidades es, por tanto, hablar de la vida de estas mismas Universidades en lo que tienen de más glorioso y alentador". Beltrán de Heredia, "La Teología de nuestras Universidades", 439.

38 "La ciencia del espíritu parece haber sido la porción que la Providencia nos ha reservado preferentemente". Beltrán de Heredia, Los orígenes de la Universidad de Salamanca, 21. 
have time to dedicate an influential study to the University of Santo Domingo in Hispaniola (1955).

With the exception of two books on Dominican "spiritual" literature during the 16th century, Beltrán de Heredia's books were generally huge collections of previously unpublished historical documents and the teachings of Dominican theologians. His prefaces - also full of archival documents - were usually over 200 pages long. From 1932 to 1952 he published the commentaries of Vitoria on the Secunda secundae in a six-volume edition. From 1944 to 1953 he published those of Báñez on the first and third parts of the Summa theologiae in five volumes. His exceptional aptitude for collecting sources is clearly apparent in his two most cited works: the Bulario (1219-1549) and the Cartulario (1218-160o) of the University of Salamanca, ${ }^{39}$ nine volumes that are essential reading for every specialist in the field.

A reader of the Cartulario and the Bulario might suspect that both titles compiled the basic sources of the 13th-16th centuries. For example, the Cartulario included one of the most important archival documents regarding the creation of the university: the 1254 charter, a royal act by which Alfonso $\mathrm{x}$ founded and endowed the university. However, Beltrán did not print most of the royal charters granted to the University of Salamanca by the Castilian and Spanish kings from Alfonso $x$ to Philip II: more than 450 relevant documents that had been published by Esperabé in 1914. The editor warned readers about his omission in the prologue to the first volume but avoided any further reference to this capital subject. ${ }^{40}$ And since Esperabé's Historia pragmática was almost inaccessible apart from in Salamanca or Madrid, historians relying on Beltrán de Heredia's compilation tended to assume that the medieval University of Salamanca depended almost entirely on the Church. That is to say, Salamanca would have had a clear pontifical or ecclesiastical character. "The studium", Beltrán argued, "although founded by the king, had been developing in the shade and with the most important collaboration coming from churchmen". ${ }^{41}$ Beltrán even cast doubts about Alfonso x's contribution to the foundation and endowment of the university, stating that "this is not entirely certain". ${ }^{42}$ Undoubtedly, royal support of the studium was very modest during

39 Beltrán de Heredia, Bulario, 3 vols.; Beltrán de Heredia, Cartulario, 6 vols.

40 "Capítulo preliminar" of the Cartulario, vol. 1, 26.

41 "El estudio, aunque fundado por el rey, venía desenvolviéndose a la sombra y con la colaboración principalísima de personal eclesiástico", Beltrán de Heredia, Los orígenes de la Universidad de Salamanca, 23.

"Esto no es del todo cierto". Beltrán de Heredia, Los orígenes de la Universidad de Salamanca, 29. On Alfonso X, he concluded, "al titularse fundador de la Universidad en la 
the 13th and 14th centuries but it was constant and had a great impact on temporary matters such as school supplies, finances, and jurisdiction. In spite of this crucial royal role, anyone who did not know of or have Esperabés Historia pragmática at their disposal would probably not have realised that the university asked the king to sanction papal letters in the 15th century. In fact, the university brought the constitutions of Pope Benedict XIII of 1411 before Juan II of Castile and, although the monarch approved them, he refused to accept the interference of any ecclesiastical conservadores, arguing that the University already had its royal conservadores. ${ }^{43}$

Beltrán de Heredia devoted a chapter of his Cartulario to compare some features of the medieval University of Salamanca with the studia of Bologna and Paris. In any case, the subject - although indispensable to properly understand the workings of his own alma mater - did not seem of much interest to him and he did not return to it in later works. ${ }^{44}$ Until the 1970s, following Beltrán de Heredia, ${ }^{45}$ Salamanca was seen as a kind of isolated and self-generated institution, which was created from nothing after the foundational bulls and charters and without any influence from contemporary European educational institutions. Aligned with the national Catholic ideology, it was taken for granted that its form of government, collegiate bodies, faculties, chairs, authors - at least in part -, and its legislation were unique and original, the result of an idealised "Spanishness". This kind of local historical pride well served the interests and perspectives that Franco's clumsy nationalist regime imposed on any kind of intellectual and cultural activities,

súplica dirigida a Alejandro vi [...] expresaba un concepto que, si no responde a la realidad histórica tal como hoy la concebimos [...]", 47 .

43 Esperabé, Historia pragmática, vol. 1, 92-94. The same thing may have occurred with those of Martín v in 1422.

44 An exception would be the rich section IX, "Constitución y régimen académico de Salamanca durante los siglos XIII, XIV y principios del XV", "Capítulo preliminar" to Beltrán de Heredia, Cartulario, vol. 1, 189-209. While Beltrán only travelled abroad after his retirement in 1948, other contemporary Catholic intellectuals spent most of their lives outside Spain. The case of the Navarrese Jesuit Ricardo García Villoslada (1900-1991) is quite exceptional. He left Spain when he was in his zos and received different teaching and research assignments in Venezuela (Colegio de Caracas), Germany (München Universität), and Italy (Università Gregoriana di Roma), where he obtained his doctoral degree and published his important and far-reaching books, La Universidad de París durante los estudios de Francisco de Vitoria O. P. (1507-1522) (Rome, 1938) and Storia del Collegio Romano (Rome, 1938), which are only a part of his intellectual production related to the fields of the history of university and the history of the Catholic Church and the Reformation.

Peset and García Trobat, "Historiografía de la Universidad de Salamanca, siglos XIX-XX". 
which aimed at isolating Spanish academia from any kind of suspicious external influences.

Due to approaches like that of Beltrán de Heredia, the history of Salamanca and other Spanish universities became a sort of appendix to Church history between the post-war period and the end of the Franco regime. ${ }^{46}$ In spite of their anachronistic and ideological perspectives, the merits of the monumental books and collections of these 2oth-century Dominicans is unquestionable.

Some non-Dominican writers also contributed to the history of the University of Salamanca, with works of great value being published in the same period. Above all, they edited compilations of documents and editions of classic authors, adopting the same apologetic and ecclesiastical approach found in Cuervo, Getino, and Carro. These tended to be the same kind of descriptive, documental histories based on legal sources which focused on publicising the most "distinguished" teachers and authors of Salamanca. They also shared the same static view that praised the glory of the "Golden Age" of the Spanish empire, while saying nothing about the reasons behind its crisis and decline.

The predominantly ecclesiastical approach described above can be explained, in part, as a result of the large number of ecclesiastical authors working in this period: 15 of them published five or more titles. In addition to the well-known Beltrán de Heredia, another Dominican played a leading role as an apologist for the order: Ramón Hernández Martín (born in 1932). The Franciscan Antonio García y García (1928-2013) was a prominent scholar in the field of medieval canon law; the Jesuit Benigno Hernández (1936-1996) examined the writings of Juan de Segovia, a Salamanca theologian of the 15th century; and the Mercedarian Vicente Muñoz Delgado (1922-1996) antagonised Dominican Thomists in favour of nominalism. Secular clergymen too were distinguished figures in many fields. Among the most important were Lamberto de Echeverría (1918-1987), canonist; José Goñi (1914-2002), editor of the appeals addressed to the pope by the university; Luis Sala Balust (19221965), who studied the statutes of the colegios mayores; Cándido María Ajo (1916-2007), responsible for an 11-volume compilation of charters and bulls from the universities of the whole "Spanish world"; and Florencio Marcos, a canon lawyer and archivist who found and published important documents and guides. Among the few women working in this highly male-dominated field, it is important to mention the Dominican nun Águeda Rodríguez Cruz (1933-), who deserves separate treatment.

46 Mariano Peset shared this historiographical perspective in several texts: see, for example, his "Prólogo" to Claustros y estudiantes, vol. 1, XIX. 
Only four laymen played a leading academic role in this period dominated by those prominent clergymen: Luciano Pereña (1920-2002), a tenacious editor and apologist of the "School of Salamanca"; Manuel Fernández Álvarez (1921-2010), perhaps the only professional historian of the group, who studied the history of the university at the beginning of the 16th century; Luis Sánchez Granjel (1920-2014), a physician interested in the study of medicine in Salamanca; and María Teresa Santander Rodríguez (1925-2012), another exceptional woman, who was a librarian for many years and also worked on the history of medicine.

Despite their longevity, most of these authors produced their most relevant writings before the death of Franco in 1975 and the subsequent cultural, social, and academic transformation of Spain. Just after and in parallel with a certain generational replacement, reforms took place in all areas of the social sciences. Integrative and dynamic views of classical objects of study, such as universities, tried to explain, for the first time, how a phenomenon or an institution was influenced by the surrounding society over time. At the same time, academics working in humanistic fields showed how far those phenomena or institutions influenced the evolution of a certain community in turn. From this period on, historians would begin their research by trying to define a challenging set of sources and problems without falling back into the linear and sometimes uncritical narratives of positivist history.

These approaches, applied for the first time to the history of education and specifically, to the history of universities -, sought to go beyond the linear accounts of the foundation and internal activity of a certain institution or educational system which were based almost entirely on legal documents, such as constitutions and charters that were uncritically glossed. Rather, the new generation of professional historians sought to convert each object of study into a complex problem far exceeding the academic environment. Instead of resorting to the classical analogies and hasty assumptions of previous scholars, they tried to show how the role and purposes of every university differed according to place and time. ${ }^{47}$

This multidisciplinary perspective introduced new social, political, and economic approaches to the various actors involved in the history of universities. The history of knowledge, science, and quantitative accounts of academic populations emerged as useful complementary perspectives and soon different authors from several countries embraced this historiographical revolution. 
This new approach was developed not only in Salamanca, but also across Spain and Latin America. Several authors have examined this general phenomenon, ${ }^{48}$ and, throughout this chapter, I demonstrate how current academics, who are interested in the history of the University of Salamanca, have a much more plural and professionalised historiography at their disposal because of this turn.

The best evidence of this spirit of renewal and transformation is the Historia de la Universidad de Salamanca, edited in four books and five volumes (2002-2009)..$^{49}$ Undoubtedly, some of the contributors were still members of the old historiographical schools, but the work has the merit of covering, for the very first time, a timeframe spanning from the origins of the university to the end of 2oth century. Lesser-known periods, however unimpressive they seem, were taken into account and studied from a multidisciplinary perspective. This work carefully reviewed the main sources and bibliography for the history of the Salamanca studium. It associated the university corporation with other institutions of the city: the cathedral, the secular cabildo (city council), and colegios mayores and menores, both secular and regular. It also explored the role of external powers, primarily the Crown and the papacy, and it addressed the relationship between university and state in the period following the liberal reforms, as well as thoroughly discussing the internal government and legislation of the institution over the centuries. Other contributors also analysed its finances and the building assets. If the sources allowed it, they quantified students, graduates, and professors, a crucial perspective in properly defining the changing character of the university throughout its changing fortunes. This Historia de la Universidad de Salamanca provided information about the life of the different faculties in the old and new regimes and about the type of knowledge cultivated in each of them until the present day. A particularly remarkable feature is that it also outlined the relationship between Salamanca and the other universities of Castile and Aragon, Portugal, the European territories of the Spanish Monarchy, and even the Indies. In conclusion, despite its shortcomings and weaknesses, it is a monumental work and an indispensable tool for re-examining Salamanca with fresh eyes.

48 A brief account, extensive to Ibero-America, in González González and Gutiérrez Rodríguez, El poder de las letras, chapter II, "Entre dos polos: la historiografía Universitaria", 109-162.

49 Rodríguez-San Pedro and Polo Rodríguez (eds.), Historia de la Universidad de Salamanca. 
Despite some clear advances, contemporary historiographical perspectives about the universities of Spanish America still follow the general lines of the Francoist nationalistic philosophy. The Dominicans Beltrán de Heredia and Águeda Rodríguez are perhaps the most paradigmatic authors of what we could call a "paternalistic" approach to educational institutions in America.

As has already been mentioned, the secularisation of 1838 had forced the Dominicans out of San Esteban, but they were allowed to return to their former home in 1892, in part because of the quatercentenary celebrations of the Columbian voyages and, in particular, in commemoration of Columbus's stay in their cloister in 1492 - even though the building was almost a ruin by this point. ${ }^{50}$ The support of Pope Leo XIII for neo-scholasticism prompted the order to rescue the memory and work of its theologians of the 16th and early 17 th centuries. It was within this context that Beltrán de Heredia studied America and its universities, but he did so guided by a certain approach that was based on two motivations: to exalt the role of his order in the evangelised lands, particularly in the sphere of education, and to popularise the theses of his fellow Dominicans, such as Matías de Paz and Vitoria, about the conquest. Beltrán addressed these subjects from 1929 onwards, ${ }^{51}$ and his thesis, although under-developed, provided the guidelines for many later studies on the universities of the Indies.

On 12 October 1936, being Franco in Salamanca, Beltrán gave a speech in the University's auditorium to commemorate the Día de la Raza (a national holiday established by King Alfonso XIII to praise the Spanish empire and the virtues of the Spanish race, nowadays called the Día de la Hispanidad) when General Millán-Astray interrupted the critical political remarks of Rector Miguel de Unamuno shouting, "Long live death! Let intelligence die!"52 In these tense circumstances, Beltrán declared:

Domination by conquest placed those people in a condition of inferiority. If we add to that their cultural and racial disadvantages, it can be

50 There is a useful summary of this in Martín García, "El ochocientos".

51 There is a detailed list of Beltrán de Heredia's publications in Rodríguez, "Reseña biobibliográfica", and those of Rodríguez Cruz are listed in Rodríguez-San Pedro and Polo Rodríguez, "Bibliografía sobre la Universidad de Salamanca", 791-796. 
understood that their submission to the conquering people was, in practice, a kind of slavery. It is not something that is surprising. ${ }^{53}$

According to Beltrán, the initial conditions of subjugation were radically transformed after the promulgation of the Leyes Nuevas in 1542. From that moment,

The situation of the Indians was privileged with regards to the situation of the Spaniards [...]. Thanks to the powerful campaign of our missionaries, and also to the stubborn insistence of Las Casas, in just 50 years the condition of those people had passed from one extreme to another, from the state of slavery in which they lived at the beginning of the century, to that of a pampered and privileged race. Since then the domination became a paternal guardianship. ${ }^{54}$

Beltrán also pointed out that the friars' ideas about the conquest and their preaching "were inspired by the highest Christian spiritualism. These are principles that, even today, have been impossible to overcome in the fight for the defence of inferior races". 55

Beltrán applied these kinds of paternalistic judgments to the history of Spanish American universities, which he conceived of as derivative and defective transplants of the Salamanca model to the American continent. "Salamanca has its subsidiary universities, such as nearly all those established in the Iberian Peninsula, and many of those that were erected in the

53 "La dominación a título de conquista situaba a aquellos pueblos en condición de inferioridad. Si añadimos a eso sus desventajas culturales y de raza, se comprende que la sumisión al pueblo conquistador se tradujese en la práctica por una especie de esclavitud. Y no hay que extrañarse de ello", Esponera Cerdán, "La intervención del padre Beltrán de Heredia O.P. en el paraninfo de la Universidad de Salamanca el 12 de octubre de 1936 ”, 77.

54 "La situación de los indios resultaba privilegiada con relación a los españoles [...]. Gracias a la enérgica campaña de nuestros misioneros, y también a la machacona insistencia de Las Casas, en poco más de cincuenta años la condición de aquellas gentes había pasado de un extremo a otro, de la esclavitud en que vivían de hecho a principios de siglo, a la de raza mimada y privilegiada. Desde entonces la dominación se convirtió en tutela paternal." Esponera Cerdán, "La intervención del padre Beltrán de Heredia O.P. en el paraninfo de la Universidad de Salamanca el 12 de octubre de 1936 ", 8o.

55 "Estaban inspiradas por el más alto espiritualismo cristiano. Son principios que aún hoy no han podido superarse en la lucha por la defensa de las razas inferiores.", Esponera Cerdán, "La intervención del padre Beltrán de Heredia O.P. en el paraninfo de la Universidad de Salamanca el 12 de octubre de 1936", 8 o. 
New World and Manila." ${ }^{56} \mathrm{He}$ based that preconceived subordinate character on the idea (not supported by corresponding documentary research) that Spanish American universities were born from "personnel that came out of it [Salamanca] and with laws inspired by its own." ${ }^{77}$ Soon, this tone of confidence that declared the universities of the Indies to be "subsidiary" institutions, as well as the insistence on their legal and statutory affinity, would gain weight.

He focused on three universities, all of his own order: the Santo Tomás in Bogotá (1923), the Santo Tomás in Quito (1925), and the Santo Domingo in Hispaniola (1954). When he started to reconstruct the history of the studium in Bogotá, he declared that he was planning a long-term research project "to trace the history of the teaching centres that the Order of Preachers erected and sustained with a heroic effort". ${ }^{8} \mathrm{He}$ also wrote,

In reviewing the history of our colonisation of America, the problem of education arises prominently and we monarchs and vassals put in a doubly praiseworthy effort to solve it. Firstly, because subordination to the Church and its teachings was imbued in all the centres of teaching [...] and secondly, because of the liberal generosity with which we sacrificed a good part of our institutions [...] to raise the cultural level of those people. ${ }^{59}$

He concluded his first approach to American universities and colleges hoping that his "modest essay [...] will help further strengthen the bonds of spiritual fraternity between the metropole and those republics who received their blood from it, and, therefore, the life, language, and enlightenment of a Christian

$5^{6} \quad$ "Salamanca tiene sus filiales, como son casi todas las establecidas en la península, y muchas de las que se erigieron en el Nuevo Mundo y la de Manila".

57 "[...] personal salido de ella [Salamanca] y con leyes inspiradas en las suyas", Beltrán de Heredia, Los orígenes de la Universidad de Salamanca, 21. In Manila there were two universities, one Jesuit and one Dominican, but the author only mentioned one of them, of course, that of his own order.

$5^{8}$ "Trazar la historia de los centros docentes que ahí erigió y sostuvo con heroico esfuerzo la Orden de Predicadores".

59 "Al revisar la historia de nuestra colonización de América surge preferentemente el problema de la enseñanza, en cuya solución monarcas y vasallos pusimos un empeño doblemente laudable. Primero, por la subordinación a la Iglesia y a sus doctrinas que se imprimió a todos los centros docentes [...] y, segundo, por el generoso desprendimiento con que sacrificamos una buena parte de nuestras instituciones [...] para levantar el nivel cultural de aquellos pueblos", Beltrán de Heredia, "Universidad Dominicana de Santa Fé de Bogotá", 5 o1. 
civilisation [that was] unique in the annals of colonisation". ${ }^{60}$ Such paternalistic, ethnocentric, and apologetic statements indicated, as has already been pointed out, a research project that aimed more at highlighting the merits of the Dominican order during colonial period than the university phenomenon. This also led him to defend the Order of Preachers in the long and harsh disputes they had with the Jesuits in the 17th century, when each order tried to annul the right of the other to have a university in the same city. These conflicts were particularly bitter and notorious both in Bogota and Quito (the object of his second essay).

While Beltrán extolled the "heroic effort" of his brothers to nurture the less developed cultures of those weak American races in the 1920s, in 1954 he bolstered this argument by describing how the majority of the friars who arrived in Hispaniola from 1510 onwards had come from the Monastery of San Esteban and the University of Salamanca, "Filled with a university spirit, they dreamed of transplanting to these distant islands the famous academy in which they had been trained". ${ }^{61}$ As we can see, there are three associated terms: branch, transplant, and Salamanca. Beltrán did not study other universities and in his later work he almost exclusively dealt with the theologians of San Esteban, however, he bequeathed a basic vocabulary that would be used for many decades to "explain" the origins of the university in the Indies.

In contrast to her older fellow Dominican, Águeda Rodríguez was on a mission to popularise the idea that the history of universities in the American viceroyalties was the result of a "projection" of Salamanca in Spanish America, and it was the only concept she used to explain the myriad of complex dynamics affecting universities of the New World. She hardly addressed any other issue in the more than 150 texts she published between 1960 and 2013, whose flashy titles usually included terms like hispanidad, alma mater, projection, influx, conducting thread, etc. To her, everything departed from Salamanca and flowed to the other side of the ocean. Rodríguez often used such concepts, adjectives, and snappy phrases in her work, for example, she gave a section of her Salmantica docet (1977) the title "Universal hymn in praise of

6o “[...] modesto ensayo [...] contribuya a estrechar más los lazos de fraternidad espiritual entre la Metrópoli y las Repúblicas que de ella recibieron la sangre y, por tanto, la vida, la lengua y las luces de una civilización cristiana única en los anales de la colonización", Beltrán de Heredia, "Conatos de la Junta de Temporalidades para suprimir la Universidad Tomista [Bogotá]”, 85 .

61 "Saturados de ambiente universitario, soñaban con trasplantar a estas lejanas islas la célebre academia en que se habían formado", Beltrán de Heredia, La autenticidad de la bula "In apostolatus culmine", base de la Universidad de Santo Domingo, 10. 
Salamanca and its most celebrated university". ${ }^{62}$ In the introductory remarks, she announced that she would address

what Salamanca's alma mater was yesterday [...] full of glory and grandeur in the 16th century [which] gave life and a similar nature to those many universities that today call it nurturing mother, alma mater [...] like a midwife who gathers and feeds her children, like the symbolic pelican that tears its chest to feed its chicks with its own blood. ${ }^{63}$

Despite her frequent rhetorical excesses and anachronistic and nationalistic prejudices, it would be unfair to ignore the many positive aspects of her publications. For example, in her Historia de las universidades Hispanoamericanas. Periodo hispánico (1973), she offered a pioneering account of universities in America and the Philippines, providing her readers with a vast bibliography and information about the archives in which the main legal sources could be found: bulls, royal decrees of erection and reform, statutes, and constitutions. Using these sources as a basis, along with the available secondary literature, she outlined the steps that led to the creation of each university and how they developed, describing, in particular, the many conflicts between the Dominicans and the Jesuits.

In 1977 Rodríguez published Salmantica docet. La proyección de Salamanca en Hispanoamérica, ${ }^{64}$ in which she offered a synthesis of the university's history and then - in the following long 38 chapters - she elaborated on the many elements of "filiation" that existed between Salamanca and certain American universities and colleges, especially through comparing the statutes and legal regulations of the mater with those of the filiae. In her later El oficio de rector en la universidad de Salamanca y en las universidades hispanoamericanas (1979), she compared the normative framework that regulated the role and deeds of

62 "Himno universal de alabanza a Salamanca y a su universidad celebérrima". In this chapter, Rodríguez Cruz amassed praises about the studies conducted there since the $15^{\text {th }}$ century, $30-32$.

63 " [...] lo que fue el Alma mater salmantina de ayer [...] pletórica de gloria y de grandeza en el siglo XVI [que] dio vida y semejanza a muchas universidades que hoy la llaman Madre nutricia, Alma mater [...] como una matrona que recoge y alimenta a sus hijos, como el simbólico pelícano que se rasga el pecho para alimentar a sus polluelos con su propia sangre", Rodríguez Cruz, Salmantica docet, 5 . The front page of the Estatutos of 1625 did in fact have a pelican, a symbol of Jesus Christ and the Eucharist.

64 Salmantica docet was also the title of her doctoral thesis (1963-1964), which was written in 12 volumes. She planned to rewrite this long dissertation in three more condensed and substantial volumes but only managed to publish the first one. 
the rector of the University of Salamanca with those that regulated the rectorships of Lima, Mexico, Caracas, Havana, and Santo Domingo, identifying 136 similarities and differences.

For the first time, Rodríguez Cruz put the legal structure of the university at the forefront, albeit with little analytical rigour. The result of her sweeping research was a monolithic scenario in which the university on the Tormes "radiated" its light towards its overseas "daughters". Despite her thorough comparison of normative bodies, the only causal relationship she highlighted related papal erection decrees and university statutes, that she conceived of as imitations of the Salamanca model. Rodríguez Cruz avoided many key questions, particularly those that would have forced her to examine the links between Salamanca and Spanish American universities and also other Iberian and European universities. When she occasionally reflected on these aspects, it was only to comment on certain paragraphs of decrees and statutes in an uncritical way.

Her explanation that Spanish-American universities emerged because of a "transplant" or "projection" was based on the argument that such "filiation" was proven by the evident textual relationship between Peninsular and American legal texts. Therefore, it would follow that the greater the textual affinity between Salamanca and an American university, the closer the similarity between the two institutions. This perspective is difficult to sustain and has been abandoned in the most recent writings about the history of SpanishAmerican universities. It also assumed that the projection occurred in a single direction, from a central transmitter to peripheral, and somehow secondary, receptors. This clearly implied that only Salmantica docet, while the "daughters" limited themselves to profiting from and preserving such a rich inheritance. On its own, Salamanca never received any kind of feedback from its daughters; in fact, Salamanca did not need any kind of feedback given its obvious sufficiency and (almost) omniscience. Such an outlook ignored contrary evidence that now seems obvious, such as the fact that if Matías de Paz and Vitoria studied the conquest, it was because the Indian subjects and American realities in general had an impact on the thinking and teaching of some of the most important masters in the Peninsula. Or even the fact that the writings of Spanish-American university professors and students circulated in the city on the Tormes. ${ }^{65}$

65 Some examples would be the famous Mexican masters Antonio Rubio (an authority in the field of logic) and Alonso de la Vera Cruz (author of a Cursus artium and specialist in theology and law), whose writings were of great interest to Salamanca and Alcalá printers. Their works circulated widely in Salamanca, Spain, and all across Europe. 
Such a thesis implied a static point of view: that a projection could remain intact, regardless of time and the changing circumstances of such distant places. Moreover, it presupposed that as soon as norms were dictated and confirmed, they defined - in body and form - a certain reality. This ignores the fact that certain laws were never anything more than a piece of paper which were not or could not be enacted, either because it was impossible in the local context, in part or in total, or because conflicts between local and imperial interests prevented them from being put into practice. Legal provisions emanating from external powers were seldom implemented if they entered into conflict with certain local interests or when prominent groups or individuals found it more attractive or profitable to disregard them, dispense with them, or violate them. Furthermore, neither the legislation of Salamanca nor that of America remained unchanged, and indeed, the changes made in the regulatory regime of the University of Salamanca did not pass ipso facto to the universities of the New World. On the contrary, the existing differences between them only grew over time. Also, the reforms applied to American educational institutions did not emanate from or depend on what was happening in Salamanca, but rather on local factors or royal will. The attempt to reduce such complex processes to the statutory affinities between two or more universities led to the regrettable neglect of the social, political, economic, academic, and even religious conditions which were behind the creation of each university and which also lay behind the need to reform their structures and norms. It is impossible to understand the "content" of legislation and the "meaning" of legal changes without rethinking the nexus between legislation and its historical context.

\section{Dictate Laws: Apply Laws?}

Under which conditions did Salamanca's legislation originate, and how did it affect the New World? ${ }^{66}$ From the very beginning, the peninsular corporation enjoyed the right to set the majority of its own regulation precisely because it was a collegiate body that was recognised by both temporal and ecclesiastical authorities. Because of this autonomy, the University of Salamanca dictated

66 This section follows closely some paragraphs of my contribution to the voice "Maestros", in the Diccionario Histórico de Derecho Canónico en Hispanoamérica y Filipinas, an editorial initiative of the Max Planck Institute for European Legal History. Some was also previously published in Spanish in González González and Gutiérrez Rodríguez, "Estudio Introductorio" to Palafox y Mendoza, Constituciones para la Real Universidad de México, $15-67$. 
regulations for specific matters as they arose, adding new dispositions to old ones with no other order than priority. Therefore, in times of conflict it was difficult to distinguish regulations that were still in force from those abrogated by disuse or more recent agreements. If a consensus was not reached, the community asked for the advice of an external arbitrator. For example, Martin v was requested to approve the constitutions of 1422 , which remained formally valid until studies were restructured in the 19 th century. ${ }^{67}$

In the 16th century, royal interventionism, with visitors as its main instrument, was an additional element to the recurrent internal crises. If the university senate (claustro) admitted an envoy from the Crown, it assigned deputies to the task of forming a new common "bolumen" and reviewing the regulations that were in use. When the senate finally approved these legal changes, they were considered to have been promulgated and had to be implemented. One of these institutional codes was printed for the first time in $1538,{ }^{68}$ and even though it was still in force two decades later when the universities of Lima and Mexico were founded, it is unlikely that either institution had a copy of them, since the University of Mexico requested one at the end of $1553 .{ }^{69}$

In 1561, Salamanca approved the statutes that were written by Diego de Covarrubias, which would become the main legal reference for the universities of Lima and Mexico in the following decades. After these were endorsed by the university, the visitor presented the new statutes to the king and they were approved and incorporated into a royal charter that transcribed the entire text, forbidding any initiative "against the content and form of the above-mentioned statutes [...] without our permission and order".70 Other visitors did the same thing and this formula soon travelled to the Indies.

As the statutes were inserted in a royal charter - an unprecedented measure -, a new juridical position began to emerge: the validity of university norms and the potential to reform them depended on royal will, rather than on the authority of the faculty. However, the corporation retained its right to be informed and to comment on proposed reforms before they were sent to the king. Little by little, the statutes lost their original character as daily agreements of the legislative senate become codes sanctioned by a higher authority.

67 Constitutiones [...] almae Salmanticensis Academiae (1625).

68 Estatutos hechos por la Universidad de Salamanca (1538).

69 The Senate of the University made this petition on 30 January 1554, "Yten, que se enviasen por los estatutos de Salamanca", Mexico, Archivo General de la Nación (AGNM), Ramo Universidad, v. 2, fol. 91v. See also González González, "Estatutos universitarios mexicanos anteriores a la visita del oidor Farfán (1580): un replanteamiento de la cuestión”, 142. "[...] contra el tenor y forma de los dichos estatutos [...] sin nuestra licencia y mandado". 
In Salamanca jargon, the word constitutions always referred to the text approved by Pope Martin v and the term statutes referred to the punctual agreements made by the senate or the codes imposed by visitors. Within the American context, the previous distinctions between the constitutions and statutes were diluted because the legislative power of the senate was far more reduced and it did not have the same ability to intervene in the daily life of the universities as that of Salamanca. The term "statute" retained part of its original corporate background but it was used, above all, to designate a specific code. Therefore, there were no longer any substantial differences between the two concepts: statutes and constitutions were used almost indiscriminately. For example, in the Mexican case, we talk about the statutes of Farfán and the constitutions of Palafox, but both were a kind of imposed regulation.

The legislation of the University of Lima emerged from a long period of conflict. The charter of 1551 ordered the university to be erected in the Dominican cloister, as long as the king did not change his mind. ${ }^{71}$ Viceroy Toledo, supported by the secular doctors, moved the university from its Dominican seat in 1571 to another place. At the same time, the claustro elected a secular rector and dictated 42 constitutions which were quickly confirmed by the viceroy. The first constitutions ordered that the university rector should always be a layman. ${ }^{72}$ The endowment (dote) and its final seat were confirmed in 1577 , and the corresponding regulations were rewritten immediately. In the meantime, the friars obtained a bull from Pius v that gave them perpetual control over the university in 1571 , making it impossible to reach the necessary agreement. A decade later, just before he left Peru, Viceroy Toledo approved the Constituciones y ordenanças de la Universidad y Studio general de la Ciudad de los Reyes del Piru, the definitive rules, so to speak, in which the university's royal character was ratified. In these Constituciones y ordenanças, the papal bull was not even mentioned. The king confirmed them some years later and they were even published in $1602 .{ }^{73}$

It is true that the Lima Code, made up of only 13 titles, was inspired by the statutes of Covarrubias, but the context in which it was approved demonstrates that it did not respond to a mere desire to copy the Salamanca model. The statutes were adapted barely five years after the opening of the San Marcos,

71 On Lima, see González González and Gutiérrez Rodríguez, El poder de las letras, 235-276.

72 Eguiguren, Historia de la Universidad, gathered all the constitutions from the 16th century, including those ordered by viceroy Martín Enríquez in 1584, which were not confirmed by the king. They have been considered more royalist than previous ones and seem to be more structured than those of Toledo, 1-2, 283-429. 
which was still an institution with an uncertain future, even though it had been erected and endowed by Toledo. In this critical period, it was important to reaffirm the royal character of the university and avoid the threat represented by the friars' ambition, hence the silence about the papal bull which granted its control to the Dominicans. The constitutions that were approved in 1581 remained unchanged for more than two centuries despite the growth of the university and the changes that affected the institution. This lack of correspondence suggests that the text soon ceased to be applied - if indeed it had ever been implemented - and that the University of Lima was mostly guided by internal agreements and royal charters. ${ }^{74}$

In 1624, new Constituciones añadidas por los virreyes marqueses de Montesclaros y príncipe de Esquilache were published, but these only intended to solve problems derived from the original endowment. ${ }^{75}$ Even if they were norms dictated from above, they still responded to the demands of the university senate because, above all, they addressed very specific obstacles hindering the development of the Lima studium. Therefore, it would be pointless to say that these norms derived from Salamanca. The old, added, and modern Constituciones antiguas, añadidas y modernas were published in $1735{ }^{76}$ and simply compiled the texts of 1581 and 1624 without any significant changes, although the editors did add several lesser-known charters. The bull of Pius $\mathrm{V}$ was also printed there for the first time but there was no corresponding royal approval: apparently it had never been negotiated. That said, there is much about the legislation of Lima that remains to be examined. ${ }^{77}$

The better-studied University of Mexico developed along very different lines. ${ }^{78}$ The founding charters of $155^{1}$ entrusted the guardianship of the university to the viceroy and the Real Audiencia, and they gave this their utmost attention. In the name of the king, the viceroy ruled the university from above and obliged the institution to recognise him as vice-patron. When the faculties of civil law and canon law were created, the oidores were incorporated as doctors and could influence the university from within. In turn, prominent canons who were part of the cathedral chapter, high-ranking friars, and renowned physicians founded the faculties of arts, theology, and medicine. In 1553, the

74 Álvarez Sánchez, "Los estatutos de las universidades reales de América".

75 Constituciones añadidas (1624).

76 Constituciones antiguas, añadidas y modernas (1735).

77 See Álvarez Sánchez, "Los estatutos de las universidades reales de América".

78 González González, "Estatutos universitarios mexicanos anteriores a la visita del oidor Farfán (1580): un replanteamiento de la cuestión”; González González and Gutiérrez Rodríguez, El poder de las letras, 212-234. 
university senate appointed its first statutes in meetings that were held before the viceroy. The proceedings of these meetings were recorded in the so-called Libro de la fundación. ${ }^{79}$ It contained agreements on chairs, the courses that needed to be taught, graduating ceremonies, and how to incorporate courses and degrees obtained in other universities (incorporaciones). At least three of the first oidores and some theologians came from Salamanca and were recruited as professors. Salamanca's collegiate model ("claustral") was adopted and can be considered as an indirect source that influenced the foundation of the Mexican studium, even in the absence of a copy of the Salamanca's statutes.

This structure was soon questioned. It was the opinion of Archbishop Alonso de Montúfar (who arrived in 1554) and other angry clerics that the viceroy and oidores had too much power. They argued that if Mexico enjoyed the privileges of Salamanca, it should be ruled according to the same Salamancan norms; and needless to say, the statutes of Salamanca did not refer to oidores or viceroys. This bitter dispute shines a light on the conflict of interest between secular and ecclesiastical powers and their competing attempts to control education. In the absence of a solution, this clash lasted more than a century until visitor Palafox established some sort of agreement in 1645, but even then the conflict did not die out completely. ${ }^{80}$

In 1564 , the visitor Juan de Valderrama tried, unsuccessfully, to find an agreement. Apparently, a draft of new statutes was written but only one page of this legal project has survived. ${ }^{81}$ Later on, Pedro Moya de Contreras, the new archbishop, supported the ecclesiastical party and succeeded in his request to the king for another visitation of the studium, but this actually backfired on him because the viceroy entrusted it to the oidor Pedro Farfán, Moya's archenemy. His statutes of 1580 reinforced, de facto, the power of the Audiencia, and he cleverly presented his code as containing nothing more than the regulations of Salamanca, but only insofar as they were applicable to Mexico. ${ }^{82}$ In 1586, Moya took advantage of his appointment as general visitor and interim viceroy to write a new code which was favourable to the clergy. The code was approved

79 Pavón Romero and González González, "La primera Universidad de México" contains a summary of these beginnings and a detailed bibliography.

8o About this particular conflict, see González González, "Oidores contra canónigos".

81 AGNM, RU, 2, 49; González González, "Estatutos universitarios mexicanos anteriores a la visita del oidor Farfán (1580): un replanteamiento de la cuestión", 116. I quoted the only known passage of the text of 1564 on 115 .

82 On Farfán and his visitation, see González González, Legislación y poderes en la universidad colonial de México (1551-1668), vol. 1, 287-306. For two opposing views see Rodríguez Cruz, "Pedro Farfán: figura cumbre de la proyección universitaria salmantina en Hispanoamérica" and Poole, "Institutionalized Corruption in the Letrado Bureaucracy: The Case of Pedro Farfán (1568-1586)". 
by the university senate, but not by the audiencia. ${ }^{83}$ In 1626 , Viceroy Cerralbo asked both parties for a new text that would be agreeable to them both, but he had to abandon the idea because of the persistent disagreements between oidores and clergymen. ${ }^{84}$

In his visitation of 1645 , Palafox faced the problem of "the disturbance of the constitutions", 85 that is to say, the arbitrary uses of the constitutions of Salamanca, Farfán, Moya, or Lima, with "the viceroys, and even the rectors, deciding about all [of them] whatever they please". ${ }^{86}$ He wanted to impose order on this chaos, saying that "If the communities do not have certain, clear, and convenient laws, they can neither respond to the intent of their formation, nor achieve the good and useful effects for which they were established". 87

Palafox convened a meeting of doctors for his project of creating a new code. He took the draft of Cerralvo as a starting point and used a new (1625) compilation of the constitutions and statutes of Salamanca - which included the constitutions of Martin V - as a reference, along with those of Moya and Lima. He managed to produce a text of great clarity which was far better structured text than that of Salamanca. Its almost impeccable expository order divided the code into six major areas:

1) Doctors and Faculties: The Collegial Government of the University (titles 2-9)

2) Chairs, Scholars, and Students (titles 10-16)

3) Degrees and Graduates (titles 17-21)

4) Holidays and Ceremonies (titles 22-24)

5) Officers and Administrative Assignments (titles 25-29)

6) Assets and Financial Management (titles 31-33)

There was also a first preliminary title where he designated the patrons of the university, and two final titles ( 34 and 35) where he fixed the penalties for every possible violation of the constitutions, and compiled the oaths sworn by the

83 González González, "Pedro Moya de Contreras (ha.1525-1592), legislador de la Universidad de México".

84 Proyecto de estatutos ordenados por el virrey Cerralvo (1626).

85 "[...] la turbación de las constituçiones".

86 "[...] arbitrando sobre todas [ellas] los virreyes, y aun los rectores, como les parecía". Letter from Olintla, 1 April 1646, Archivo General de Indias (AGI), Patronato 244, R. 14. See also Mancebo, "Unas cartas del obispo Juan de Palafox al rey", 36, 51. Letter from Puebla, 28 October 1645, Archivo Duque del Infantado (ADI), v. 35, fols. 140-149.

87 "Si no tienen leyes las comunidades, çiertas, claras y convenientes, no pueden obrar al intento de su formación, ni conseguir los buenos y útiles efectos para que se establecieron". 
university rector, consiliarios (advisors), lecturers, students, graduates, and minor officials. ${ }^{88}$

Palafox's scheme, despite some important local singularities, followed, above all, many of the standard rules corresponding to royal corporations in this period. Common to other constitutions and statutes, this legal text regulated the election of the rector, advisors (consiliarios), and deputies (diputa$d o s$ ), and defined their roles. It declared the duties and rights of doctors and designated the claustros as the highest collegiate body of government. It established faculties and chairs and the salaries of teachers. The texts also regulated the academic competition that candidates had to pass to obtain a chair, establishing clear rules about how these were to be held and the results communicated. Eligibility requirements were also carefully detailed. Dubious practices that had to be avoided, even if they were common, were also changed. Student privileges and duties were an important part of the constitutions as well. Another important theme that was regulated in detail was the requirements that had to be fulfilled in order to grant bachelor's degrees, and the courses that students should attend in each faculty to obtain this degree. The same attention was given to those required for the licentiate and doctoral degrees. They also clearly defined the officials who worked at the institution (secretary, treasurer, custodian, etc.), their duties, and salaries. The university's finances were an important focus as well: royal subsidies and other assets were listed and regulated as well as the rights for matriculation, degrees, and assignment of chairs; and how the university arca (treasury chest) was to be accessed and administered was described.

The regulations of a royal corporation provided an ideal blueprint for a complex structure and how it was to evolve, at times mentioning things of minimal significance. A different question is to what extent, if any, they were actually applied. In contrast, the norms of universities managed by religious orders tended to be very concise. ${ }^{89}$ Each order had its own rule which regulated its everyday life, including studies. For that reason, university statutes were a kind of annex to those internal regulations, and simply dealt with enrolment, courses, degrees, and ceremonies. They did not define matters such as the election of the rector and consiliarios, meetings of claustros, provisions of chairs, finances, etc., because these were already defined by the rule. Therefore, these kinds of statutes rarely exceeded five pages and frequently copied one another. It was only in the 18 th century that more complex codes started to be

88 Palafox y Mendoza, Constituciones.

89 González González, "Los estatutos de las universidades coloniales del clero regular". 
written. Sometimes, there were no statutes in these institutions, as the prior of Santo Domingo in Hispaniola acknowledged in 1728: his university (founded in 1538) had not drawn them up yet. ${ }^{90}$ Or they had fallen into such disuse that no member of the order remembered them.

We know the statutory regulations of 12 of the approximately 20 institutions run by religious orders. Most of these legal documents were written after the 1620 s, and after the bulls and royal charters that allowed their colleges or monasteries to grant university degrees had been received. In no way can these 17th-century regulations be considered to have derived from a presumed filiation to Salamanca, which was not even mentioned in these codes. Regardless of the question of whether or not those universities were subject to clearly defined regulations, there is much evidence that while some of them enjoyed a high degree of order and financial control, others profited from their privileges by selling university degrees. Statutes regulating the universities of mendicant orders have been edited, albeit not always following the best criteria, but remain understudied. However, it is the lack of a comparative approach above all which is sorely lacking in the historiography of these legal codes. ${ }^{91}$

Little is also known about the university-seminaries of Huamanga and Cuzco, but both of them had statutes. ${ }^{92}$ Caracas University was carefully studied by Ildefonso Leal, and he published its main legal sources: constitutions, charters, and many other documents about its faculties. ${ }^{93} \mathrm{It}$ seems that its regulatory regime largely resembled those of royal universities and so each important change was sent to the Crown for approval.

To sum up, university regulations in colonial Spanish America did not correspond to a single scheme or model. There was no certain, transplanted framework acting as the decisive factor behind their origins, development, and success. Some universities and colleges that granted degrees lacked codified statutes or, if they did, did not have them approved by the king or the Audiencia. In other cases, they were forgotten for decades or centuries. They were also the object of bitter controversies and there is much uncertainty about whether or to what extent they actually were enacted in many cases.

90 González González and Gutiérrez Rodríguez, El poder de las letras, 284.

91 González González, "Los estatutos de las universidades coloniales del clero regular".

92 See the commemorative publication, Universidad de San Cristóbal de Huamanga 16771977. Libro jubilar en homenaje al tricentenario de su fundación; Villanueva Urteaga, Fundación de la Universidad Nacional de San Antonio Abad; González González and Gutiérrez Rodríguez, El poder de las letras, 448-465.

93 Leal, Historia de la Universidad de Caracas; González González and Gutiérrez Rodríguez, El poder de las letras, 466-474. 
For example, in Mexico there was no consensus about the code that was to be applied for more than a century, and even the promulgation and publication of Palafox's Constituciones in 1668 was not the final word. A century later, in 1775, neither the secretary nor the doctors of the claustro knew about any copy, apart from the one belonging to a doctor, whose book was employed to reprint the code. ${ }^{94}$ Despite such an absence of clearly defined positive laws, the archival records of the institution reveal that it functioned well and regularly.

Therefore, thinking about Spanish-American universities as "renewals" or "transplants" of the alma mater Salmanticensis because of a certain affinity between their regulations is historiographical nonsense. Universities were born in the Middle Ages and expanded throughout Europe in the following centuries, also reaching the Spanish territories of America and the Philippines. As part of the same tradition, they all shared similarities - like their corporate character, their manner of teaching, and the granting of degrees -, but each university also had its own particularities which derived from specific circumstances and did not have much to do with the influence of this or that regulation.

Beyond the Rules: Readers, Graduates, and Readings

Having highlighted the scarce practical relevance of the relationship between the legal bodies of the University of Salamanca and the statutes of some Spanish-American universities, I would now like to briefly call attention to other aspects that, even if not very innovative, might perhaps be more fruitful for trying to determine the relationships between the University of Salamanca and those in the New World.

The first seeks to focus on people. Of the four oidores who were involved in the foundation of the University of Mexico in 1553, three had obtained their licentiate degrees in law from the University of Salamanca ${ }^{95}$ Bartolomé Melgarejo, who was the first reader of Decree at the university for a short time and a lawyer of the Audiencia, had been trained in Salamanca, as well as Mateo Arévalo Sedeño, who held the chair of canon law from 1554 to 1570. Fray Alonso de la Vera Cruz, dean of theology and first professor of biblical studies, too had

94 González González, "La reedición de las constituciones universitarias de México (1775) y la polémica antiilustrada", 92.

95 González González, Legislación y poderes en la universidad colonial de México (1551-1668), vol. 1, 129; Pavón Romero, El gremio docto. Organización corporativa y gobierno en la Universidad de México en el siglo XVI. 
obtained degrees in theology and perhaps canon law at Salamanca after studying arts in Alcalá. ${ }^{96}$ Rodríguez Cruz has compiled several lists of Salamanca graduates in the New World and, even though they are not exhaustive, they refer to office holders throughout the whole Spanish-American territory. ${ }^{97}$ However, a methodological problem might arise if we overestimate the significance of these lists insofar as the careers of graduates from other institutions will be ignored, making difficult to offer a fair assessment of the real degree of influence exerted by graduates of Salamanca.

In 1997, a study on the "American projection" of Alcalá de Henares and Sigüenza also produced lists of various students or graduates of those universities. Among others, they produced 16 archbishops, four prelate-viceroys, 44 bishops, three inquisitors and 42 oidores. ${ }^{98}$ These men generally seem to have held middle-ranking offices in different regions of the empire before obtaining these high-ranking positions. Leonel de Cervantes is a good example of this high degree of mobility and the circulation of trained professionals throughout the empire. Born in Mexico, he graduated from Sigüenza in 1603 and then returned to America after receiving an ecclesiastical benefice in the cathedral chapter of Santafé (modern-day Bogotá). He later became bishop of Santa Marta (Nueva Granada), Guadalajara (Mexico), and finally Antequera (Mexico), where he died in $1636 .{ }^{99}$ There are very few studies on "minor" universities such as Sigüenza and Valladolid, whose graduates also participated in the secular and ecclesiastical government of the vast Spanish empire. In fact, almost nothing is known about men who trained at universities such as Seville, Granada, and Ávila.

In these higher echelons of the administration, mobility strongly depended on metropolitan appointments. If a professor left a certain university, it was rarely because of a promotion, and he would have to go through an admissions process, confirmation of his previous degrees, and win the competition process in the new university. This was the rule for peninsulares and criollos and it also affected laymen, clerics, and friars, who moved following their superiors' orders.

Besides, little attention has been given to the analysis of the trajectories of those learned Spanish-American men who, after training or having

96 See the chapters of Folch, Aspe Armella, and Egío in this volume.

97 Among others, Rodríguez Cruz, "Profesores salmantinos en América".

98 Alonso, Casado and Ruiz, Las universidades de Alcalá y Sigüenza y su proyección institucional americana.

99 Alonso, Casado and Ruiz, Las universidades de Alcalá y Sigüenza y su proyección institucional americana, 175 . 
completed their first teaching assignments in America, travelled to Europe. Some even published books which were read and circulated in Salamanca, sometimes in manuscript copies. Fray Alonso de la Vera Cruz is presently the best-known example of such a man but although his case was exceptional, it was not unique. Vera Cruz taught in Tiripetío (modern-day Michoacán) and in Mexico City, where he published four philosophical, theological, and legal treatises between 1554 and 1557, which together were reprinted ten times in Salamanca in the following two decades, precisely when the university was at its peak. Some of these writings, as parts of a manual for the cursus artium, even competed in the developing editorial market with the famous manuals of his teacher, Domingo de Soto. The Speculum coniugiorum was particularly important, and it was printed in Mexico in 1556, ${ }^{100}$ Salamanca in 1562, ${ }^{101}$ Alcalá de Henares, the other great university city in Castile, in $1572,{ }^{102}$ and even Milan in $1599 .{ }^{103}$ In this treatise, as Egío's contribution to this book shows well, Vera Cruz dealt - in a very abstract, general, and erudite way - with the "local" issue of marriage customs among the Indians and the canonical problems that some of those different customs had generated. In short, until now we have studied the journey from Salamanca to the Indies, but future research should also focus on the return voyage to the eastern Atlantic and the River Tormes.

\section{Bibliography}

\section{Manuscripts}

Archivo Duque del Infantado, Madrid (ADI), v. 35 (before 85).

Archivo General de la Nación, México (AGNM), Ramo Universidad, v. 2.

Archivo General de Indias, Sevilla (AGI), Patronato 244, R. 14.

\section{Printed Sources}

Estatutos hechos por la Universidad de Salamanca, Salamanca 1538.

Estatutos hechos por la Universidad de Salamanca, año de 1561, Salamanca 1561. Also in Esperabé, Enrique, Historia pragmática e interna de la Universidad de Salamanca, vol. 1, Salamanca 1914, 217-356.

Constituciones y ordenanças de la universidad, y studio general de la ciudad de los Reyes del Piru, Ciudad de Los Reyes [Lima] 1602.

100 Vera Cruz, Speculum coniugiorum, published in Mexico by Juan Pablo Bricense.

101 Vera Cruz, Speculum coniugiorum, published in Salamanca by Andrea de Portonaris.

102 Vera Cruz, Speculum coniugiorum, published in Alcalá by Juan Gracián.

103 Vera Cruz, Speculum coniugiorum cum appendice, published in Milan by Pacifico Ponti. 
Constituciones añadidas por los virreyes, marqués de Montesclaros, y principe de Esquilache, a las que hizo el virrey don Francisco de Toledo para la real universidad y estudio general de San Marcos de la ciudad de Los Reyes del Piru [...], Madrid 1624.

Constituciones apostolicas, y estatutos de la muy insigne Universidad de Salamanca (1625), facsimile ed. without the Pontifical Constitutions, Salamanca 1990.

Constituciones de la Universidad de Lima, siglo XVI, in Eguiguren, Luis Antonio (ed.), Historia de la Universidad. Tomo I, La Universidad en el siglo XVI, vol. I, 2, Lima 1951.

Constitutiones tam commodae aptaeque, quam sanctae almae Salmanticensis Academiae ...; in Constituciones apostolicas y estatutos de la muy insigne Universidad de Salamanca, vol. 1, Salamanca 1625, 3-72.

Fuero de Salamanca, ed. by Sánchez Ruano, Julián, Salamanca 1870.

Proyecto de estatutos ordenados por el virrey Cerralvo (1626), ed. by González González, Enrique, México 1991.

Palafox y Mendoza, Juan de, Constituciones para la Real Universidad de México (1645), ed. by González González, Enrique and Víctor Gutiérrez Rodríguez, México 2017.

Sacrosanto y ecuménico concilio de Trento, Madrid 1785: Ignacio López de Ayala.

Vera Cruz, Alonso de la, Speculum coniugiorum, México 1556: Juan Pablo Bricense.

Vera Cruz, Alonso de la, Speculum coniugiorum, Salamanca 1562: Andrea de Portonaris. Vera Cruz, Alonso de la, Speculum coniugiorum, Alcalá 1572: Juan Gracián.

Vera Cruz, Alonso de la, Speculum coniugiorum cum appendice, Milano 1599: Pacifico Ponti.

\section{Literature}

Ajo González de Rapariegos y Sáinz de Zúñiga, Cándido María, Historia de las universidades hispánicas: orígenes y desarrollo desde su aparición a nuestros días, 11 vols., Ávila-Madrid 1957-1979.

Alonso, Pedro Manuel, Manuel Casado and Ignacio Ruiz, Las universidades de Alcalá y Sigüenza y su proyección institucional americana. Legalidad, modelo y estudiantes universitarios en el Nuevo Mundo, Alcalá de Henares 1995.

Álvarez Sánchez, Adriana, "Los estatutos de las universidades reales de América", in Casanova, Hugo, Enrique González González and Leticia Pérez Puente (eds.), Universidades de América: ayer y hoy, México 2019, 45-89.

Álvarez, Adriana, Dos reales y obediencia al rector. Los estudiantes de la Real Universidad de San Carlos (1699-1821), [ongoing study].

Bellomo, Manlio, Saggio sull'università nell'età del diritto comune, Catania 1979.

Beltrán de Heredia, Vicente, "Conatos de la Junta de Temporalidades para suprimir la Universidad Tomista [Bogotá]", in Ciencia tomista 85 (1924), 59-85.

Beltrán de Heredia, Vicente, "La Teología de nuestras Universidades en el Siglo de Oro", in Analecta Sacra Tarraconensia 14 (1941), 1-29 and in Beltrán de Heredia, Vicente, Miscelánea Beltrán de Heredia, vol. 4, Salamanca 1973, 439-465. 
Beltrán de Heredia, Vicente, Los orígenes de la Universidad de Salamanca, Salamanca 1953 .

Beltrán de Heredia, Vicente, La autenticidad de la bula "In apostolatus culmine", base de la Universidad de Santo Domingo, puesta fuera de discusión, Trujillo 1954.

Beltrán de Heredia, Vicente, "Universidad Dominicana de Santa Fé de Bogotá, in Beltrán de Heredia, Vicente, Miscelánea Beltrán de Heredia, vol. 4, Salamanca 1973, 501-559.

Beltrán de Heredia, Vicente, Bulario de la Universidad de Salamanca, 3 vols., Salamanca $1966-1967$.

Beltrán de Heredia, Vicente, Cartulario de la Universidad de Salamanca, 6 vols., Salamanca 1970-1973.

Beltrán de Heredia, Vicente, Miscelánea Beltrán de Heredia, 4 vols., Salamanca 1971-1973.

De Ridder-Symoens, Hildegarde (ed.), A History of the University in Europe, vols. 1-2, 3 vols., Cambridge 1992-1996.

Duve, Thomas, "The School of Salamanca. A Case of Global Knowledge Production", in Duve, Thomas, José Luis Egío García and Christiane Birr (eds.), The School of Salamanca: A Case of Global Knowledge Production (Max Planck Studies in Global Legal History of the Iberian Worlds, Vol. 2), Leiden 2020, 1-42.

Esperabé y Arteaga, Enrique, Historia pragmática e interna de la Universidad de Salamanca, 2 vols., Salamanca, 1914-1917.

Esponera Cerdán, Alfonso, "La intervención del padre Beltrán de Heredia O.P. en el paraninfo de la Universidad de Salamanca el 12 de octubre de 1936", in Nuevas de Indias. Anuario del CEAC 2 (2017), 54-85.

Falcón, Modesto, Cristóbal Colón y la Universidad de Salamanca, Salamanca 1881.

Fuente, Vicente de la, Historia de las universidades y colegios y demás establecimientos de enseñanza en España, 4 vols., Madrid 1884-1889.

García y García, Antonio, "Génesis de la Universidad de Salamanca”, in Rodríguez-San Pedro, Luis Enrique and Juan Luis Polo Rodríguez (eds.), Historia de la Universidad de Salamanca, vol. 1, 5 vols., Salamanca 2002, 21-38.

Gil de Zárate, Antonio, De la instrucción pública en España, Madrid 1855.

González González, Enrique, Legislación y poderes en la universidad colonial de México (1551-1668), PhD in history, 2 vols., Valencia 1990.

González González, Enrique, "La reedición de las constituciones universitarias de México (1775) y la polémica antiilustrada", in Alvarado, Lourdes (ed.), Tradición y reforma en la Universidad de México, México 1994, 57-108.

González González, Enrique, "Estatutos universitarios mexicanos anteriores a la visita del oidor Farfán (1580): un replanteamiento de la cuestión”, in Ramírez, Clara and Armando Pavón (eds.), La universidad novohispana: corporación, gobierno y vida académica, México 1996, 96-153. 
González González, Enrique, "Pedro Moya de Contreras (ha. 1525-1592), legislador de la Universidad de México", in Peset, Mariano (ed.), Doctores y escolares. II congreso internacional de historia de las universidades hispánicas (Valencia, 1995), vol. 1, 2 vols., Valencia 1998, 195-219.

González González, Enrique, "Oidores contra canónigos. El primer capítulo de la pugna en torno a los estatutos de la real universidad de México, 1553-1570", in Pérez Puente, Leticia and Gabino Castillo (eds.), Poder y privilegio: Cabildos eclesiásticos en Nueva España, siglos XVI al XIX, México 2016, 49-72.

González González, Enrique, "Maestros (DCH) (Masters (DCH))", Max Planck Institute for European Legal History Research Paper Series No. 202O-23, (http://dx.doi.org/ 10.2139/ssrn.3720521).

González González, Enrique, "Los estatutos de las universidades coloniales del clero regular (1622-1625)”, in Casanova, Hugo, Enrique González González and Leticia Pérez Puente (eds.), Universidades de Iberoamérica: ayer y hoy, México 2019, 91-125.

González González, Enrique and Víctor Gutiérrez Rodríguez, "Estudiantes y graduados en Córdoba del Tucumán. Fuentes y avances de investigación (1670-1854)", in Correa, Jorge (ed.), Matrícula y lecciones. XI Congreso Internacional de Historia de las Universidades Hispánicas, vol. 1, 2 vols., Valencia 2012, 431-456.

González González, Enrique and Víctor Gutiérrez Rodríguez, El poder de las letras. Por una historia social de las universidades de la América hispana en el periodo colonial, México 2017.

Goñi Gaztambide, José, “Tres rótulos de la universidad de Salamanca de 1381, 1389 y 1393", in Anthologica Annua 11 (1963), 227-336.

Hernández Díaz, José María, "El ochocientos. 2. De la Ley Moyano al siglo XX", in Fernández Álvarez, Manuel (ed.), La Universidad de Salamanca, vol. 1, 2. vols., Salamanca 1990, 203-227.

Julia, Dominique, Jacques Revel and Roger Chartier (eds.), Les Universités Européennes duXVIe au XVIIIe siècle. Histoire sociale des populations étudiantes, 2 vols., Paris 1986.

Leal, Ildefonso, Historia de la Universidad de Caracas (1721-1827), Caracas 1963.

Luna Díaz, Lorenzo, "Universidad de estudiantes y universidad de doctores: Salamanca en los siglos XV y XVI”, in Marsiske, Renate (ed.), Los estudiantes, Trabajos de historia y sociología, México 1998, 15-55.

Mancebo, María Fernanda, "Unas cartas del obispo Juan de Palafox al rey sobre las constituciones de México", in Peset, Mariano (ed.), Claustros y estudiantes. Congreso internacional de historia de las universidades americanas y españolas en la edad moderna, Valencia, noviembre de 1987, vol. 2, 2 vols., Valencia 1989, 29-43.

Martín García, María José, "El ochocientos”, in Fernández Álvarez, Manuel (ed.), La Universidad de Salamanca, vol. 1, 2. vols., Salamanca 1989, 9-61.

Martínez López-Cano, María Pilar (ed.), La Universidad Novohispana en el siglo de oro. A cuatrocientos años de El Quijote, México 2006. 
Pavón Romero, Armando, El gremio docto. Organización corporativa y gobierno en la Universidad de México en el siglo XVI, Valencia 2010.

Pavón Romero, Armando and Enrique González González, "La primera Universidad de México", Maravillas y Curiosidades. Mundos inéditos de la Universidad, México 2004, 39-55.

Peset, Mariano, Obra dispersa. La Universidad de México, México 2011.

Peset, Mariano, "Historia cuantitativa y población estudiantil", in Peset, Mariano, Obra dispersa. La Universidad de México, México 2011, 203-222.

Peset, Mariano, "La corporación en sus primeros siglos, XIII-XV", in Rodríguez-San Pedro, Luis Enrique and Juan Luis Polo Rodríguez (eds.), Historia de la Universidad de Salamanca, vol. 2, 5 vols., Salamanca 2004, 19-35.

Peset, Mariano, "Prólogo", in Peset, Mariano (ed.), Claustros y estudiantes. Congreso internacional de historia de las universidades americanas y españolas en la edad moderna, Valencia, noviembre de 1987, vol. 2, 2 vols., Valencia 1989, XI-XXXII.

Peset, Mariano and José Luis Peset, La universidad española. Siglos XVIII y XIX. Despotismo ilustrado y revolución liberal, Madrid 1974.

Peset, Mariano and Juan Gutiérrez Cuadrado, "Clérigos y juristas en la baja edad media castellano-leonesa", in Senara. Revista de filoloxia 3:2 (1981), 7-110.

Peset, Mariano and Enrique González González, "Las facultades de Leyes y cánones", in Fernández Álvarez, Manuel (ed.), La Universidad de Salamanca, vol. 2, 2 vols., Salamanca 1990, 9-61.

Peset, Mariano and Pilar García Trobat, "Historiografía de la Universidad de Salamanca, siglos XIX-XX", in Rodríguez-San Pedro, Luis Enrique and Juan Luis Polo Rodríguez (eds.), Historia de la Universidad de Salamanca, vol. 4, 5 vols., Salamanca 2009, 389-434.

Poole, Stanford, "Institutionalized Corruption in the Letrado Bureaucracy: The Case of Pedro Farfán (1568-1586)", in The Americas 38 (1981), 149-171.

Ramírez, Hernán, La Universidad de Córdoba. Socialización y reproducción de la élite en el periodo colonialy principios del independiente, Córdoba 2002.

Ramírez González, Clara, "Proyección en América: una perspectiva americana", in Rodríguez-San Pedro, Luis Enrique and Juan Luis Polo Rodríguez (eds.), Historia de la Universidad de Salamanca, vol. 3-2, 5 vols., Salamanca 2006, 1327-1350.

Real de la Riva, César, La Universidad de Salamanca. Apunte histórico, Salamanca 1953. Rodríguez, Victorino, "Reseña biobibliográfica de Vicente Beltrán de Heredia, O.P., in Beltrán de Heredia, Vicente, Miscelánea Beltrán de Heredia, vol. 4, 4 vols., Salamanca 1973, 613-647.

Rodríguez Cruz, Águeda, "Pedro Farfán: figura cumbre de la proyección universitaria salmantina en Hispanoamérica”, in Revista de Indias 31 (1971) 221-310.

Rodríguez Cruz, Águeda, Historia de las universidades hispanoamericanas. Período hispánico, 2 vols., Bogotá 1973. 
Rodríguez Cruz, Águeda, Salmantica docet. La proyección de la Universidad de Salamanca en Hispanoamérica, 2 vols., Salamanca 1977.

Rodríguez Cruz, Águeda, El oficio de rector en la Universidad de Salamanca y en las universidades hispanoamericanas, Salamanca 1979.

Rodríguez Cruz, Águeda, "Profesores salmantinos en América" in Primeras Jornadas sobre la presencia universitaria española en la América de los Austrias (1535-1700), Alcalá de Henares 1987, 42-66.

Rodríguez Cruz, Águeda, Historia de la Universidad de Salamanca, Salamanca 1990.

Rodríguez Cruz, Águeda, "Proyección en América: una perspectiva española", in Rodríguez-San Pedro, Luis Enrique and Juan Luis Polo Rodríguez (eds.), Historia de la Universidad de Salamanca, vol. 3-2, 5 vols., Salamanca 2006, 1229-1325.

Rodríguez-San Pedro, Luis Enrique, "Bibliografía”, in Fernández Álvarez, Manuel (ed.), La Universidad de Salamanca, vol. 2, 2 vols., Salamanca 1990, 6o1-641.

Rodríguez-San Pedro, Luis Enrique and Juan Luis Polo Rodríguez, "Bibliografía sobre la Universidad de Salamanca (1800-2007)", in Rodríguez-San Pedro, Luis Enrique and Juan Luis Polo Rodríguez (eds.), Historia de la Universidad de Salamanca, vol. 4, 5 vols., Salamanca 2009, 639-836.

Rodríguez-San Pedro, Luis Enrique and Juan Luis Polo Rodríguez (eds.), Historia de la Universidad de Salamanca, 5 vols., Salamanca 2002-2009.

Rodríguez-San Pedro, Luis Enrique, Juan Luis Polo Rodríguez and Francisco Javier Alejo Montes, "Matrículas y grados, siglos XVI-XVIII", in Rodríguez-San Pedro, Luis Enrique and Juan Luis Polo Rodríguez (eds.), Historia de la Universidad de Salamanca, vol. 2, 5 vols., Salamanca 2004, 6o7-663.

Sánchez de la Campa, Juan Miguel, Historia filosófica de la instrucción pública en España, desde sus primitivos tiempos hasta el día, 2 vols., Burgos 1871-1872.

Sánchez y Sánchez, Daniel, "Catedral y universidad, una relación secular", in Rodríguez-San Pedro, Luis Enrique and Juan Luis Polo Rodríguez (eds.), Historia de la Universidad de Salamanca, vol. 1, 5 vols., Salamanca 2002, 405-433.

Stone, Lawrence (ed.), The University in Society, 2 vols., Princeton 1974.

Tormo Camallonga, Carlos, El Colegio de Abogados de Valencia. Entre el antiguo régimen y el liberalismo, Valencia 2004.

Universidad de San Cristóbal de Huamanga, 1677-1977. Libro jubilar en homenaje al tricentenario de su fundación, Ayacucho [Lima] 1977.

Villanueva Urteaga, Horacio, Fundación de la Universidad Nacional de San Antonio Abad, Cuzco 1987. 